\title{
Effect of Equatorial Long Waves on the North Equatorial Countercurrent
}

\author{
T. Y. TANG, Y. J. YANG ${ }^{1}$ AND MIUG-CHIN Wu ${ }^{2}$
}

\begin{abstract}
An analytical, reduced-gravity, equatorial long wave model is employed to study the effect of equatorial long waves on the North Equatorial Countercurrent (NECC). This model is first forced by an abruptly switched-on-off zonal wind stress which is distributed uniformly in the zonal direction. As the wind is turned on, an eastward current with a maximum speed at $5{ }^{\circ} \mathrm{N}$ and a trough of thermocline at $3{ }^{\circ} \mathrm{N}$ are generated in the western basin. These features coincide with the observed distribution of NECC. The initial intensification of this eastward current is due to the forced first meridional mode Rossby wave. The duration of intensification is related to the wind fetch and Rossby wave speed. After the forced Rossby wave has passed, the eastward current is decelerated or accelerated by a series of reflected Rossby waves generated at the eastern boundary. As the steady state is reached, the easterly wind is then turned off. The forced first meridional mode Rossby wave, now generated by wind relaxation, decelerates the eastward current and even turns the current westward, due to overshooting.

Replacing the uniform wind with a linear wind, we find that the general features remain unchanged but the NECC now has larger amplitude and smaller zonal domain. The present linear wind has similar zonal distribution to the trade wind on the tropical Atlantic Ocean.

Finally, the linear wind stress distribution, with a representative of time variations observed along the equator, is applied to force the model. The resultant ocean response is compared with the velocity measurement at $6^{\circ} \mathrm{N}, 28^{\circ} \mathrm{W}$. General agreement is found. The equatorial long waves, especially the forced Rossby waves, have significant impact upon the NECC.
\end{abstract}

\section{INTRODUCTION}

The North Equatorial Countercurrent (NECC) is a swift eastward current which is located around $3^{\circ} \mathrm{N}$ to $10^{\circ} \mathrm{N}$. North of the NECC is a westward North Equatorial Current (NEC) and south of the NECC is a westward South Equatorial Current (SEC). A large

1 Institute of Oceanography, National Taiwan University, Taipei, Taiwan, R.O.C.

2 Department of Atmospheric Sciences, National Taiwan University, Taipei, Taiwan, R.O.C. 
amount of water, heat, and salt are transported from the western to the eastern tropical ocean by the NECC. The transport amount is quite comparable with the Gulf Stream (Richardson and Reverdin, 1987). The NECC undergoes a very distinguished seasonal variation; it builds up abruptly as the trade wind intensifies in the boreal spring and abruptly collapses as the trade wind relaxes in the early winter. The dynamics of this seasonal variation have been discussed by Richardson and Reverdin (1987). The curl of the local wind stress (Garzoli, and Katz 1983) and the equatorial Rossby wave (Delcroix et al. 1991) are the most likely mechanisms for controlling the NECC variation. In this paper, a simple equatorial analytical model forced by an easterly wind stress is applied to investigate the effect of equatorial long waves on the NECC. Since the model is analytical, the variation of NECC related with any individual wave can be traced.

The paper is organized into 4 sections. Previous studies of the seasonal variation of the NECC are reviewed in Section 2. The temporal and spatial variation of the wind stress and the NECC on the equatorial Atlantic Ocean are described. In Section 3, the results from an analytical equatorial long wave model, forced by various types of wind, are used to study the effect of equatorial long waves on the NECC. The domain of the analytical model is similar to the basin of the equatorial Atlantic Ocean. A switched-on-off zonal wind stress is first applied to force the model. The model responses with no boundary, western boundary only and western and eastem boundaries are examined. Finally, the model is forced by a zonal wind stress which is more complicated but realistic. The result is studied and compared to the observed velocity and at $6^{\circ} \mathrm{N}, 28^{\circ} \mathrm{W}$. Section 4 provides the discussion and conclusion.

\section{BACKGROUND}

Richardson and Reverdin (1987), using data gathered by surface drifters, current meters, and ship drifts, gave a general description of the seasonal variation of the NECC in the tropical Atlantic Ocean. They concluded that the seasonal cycle of the NECC is very regular from year to year. Each year the NECC starts up west of $18^{\circ} \mathrm{W}$ in May-June and disappears or reverses from about January-February. The origin of the NECC is the North Brazil Current which carries heat from the south to the north, crossing the equator. It flows northwest, with a speed of up to $143 \mathrm{~cm} \mathrm{sec}^{-1}$, along the western boundary. Figure 1 shows the average speed of the NECC along $28^{\circ} \mathrm{W}$ in July. The meridional distribution of NECC is not symmetrical. The maximum eastward current occurs at $5^{\circ} \mathrm{N}$. The zonal velocity gradient is larger south of this latitude than north. Similar results were obtained by analyzing historical data (Garzoli and Katz, 1983) and ship drifts (Richardson and Walsh, 1986). Hénin and Hisard (1987) analyzed data from nine cruises, collected during the Programme Français Océan et Climat dans l'Atlantique Equatorial (FOCAL) experiment. They found that the NECC underwent a distinguished seasonal cycle, but that the cycle could be significantly modified by interannual variation. 


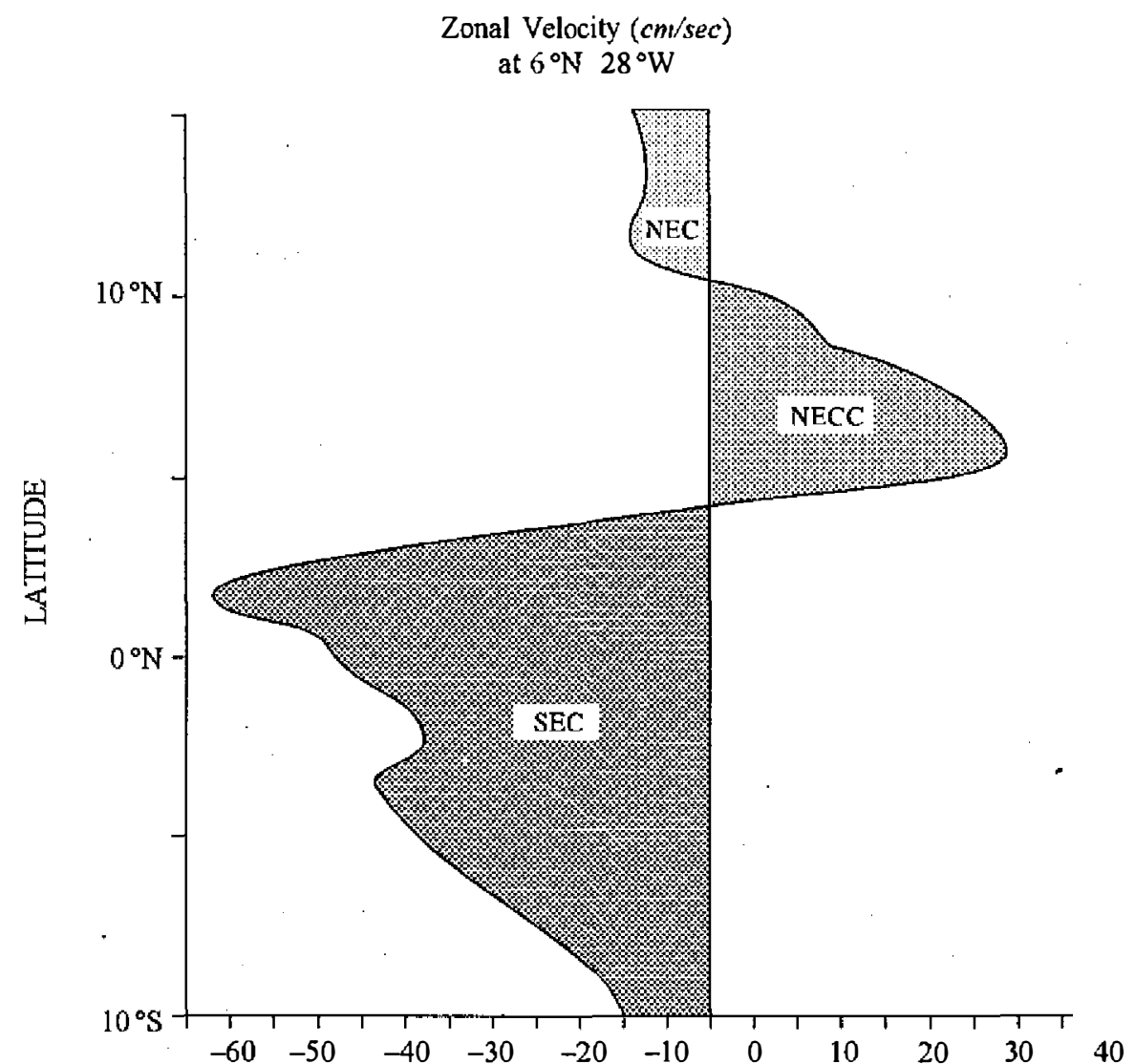

Fig. I The average zonal velocity for July in the North Equatorial Countercurrent (NECC), South Equatorial Current (SEC) North Equatorial Current (NEC) near $28^{\circ} \mathrm{W}$ from the historical ship drift. (After Richardson and Reverdin, 1987).

Using a three dimensional numerical model, Philander and Pacanowski (1986) described the transport of NECC in detail. They found that the eastward transport of the NECC decreases in a downstream direction primarily because of downwelling. This downwelling water flows along the thermocline and then injects into the Equatorial Undercurrent (EUC). The eastward transport between $2.5^{\circ} \mathrm{N}$ and $10^{\circ} \mathrm{N}$ in the upper $317 \mathrm{~m}$ is greatly reduced from west to east. The variation of transport is related with the variation of thermocline. No explicit explanation was offered by them to account for the dynamics of the NECC.

By analyzing historical data, Garzoli and Katz (1983) concluded that the variation of NECC is controlled by the curl of wind stress. This conclusion somewhat disagrees with the finding by Kessler (1990), who found that the wind stress curl has very little variability over the annual period in the north tropical Pacific, whereas the NECC has large annual variation. By examining the annual fluctuation of $20^{\circ} \mathrm{C}$ isotherm depth, he found a west- 
ward propagating Rossby wave near $5^{\circ} \mathrm{N}$. A similar feature was found by Meyers (1979) in the Pacific Ocean and by Steger and Carton (1991) in the Atlantic Ocean. Using Geosat data, Delcroix et al. (1991) discovered more evidence that the NECC is strongly influenced by the equatorial Rossby long wave.

A time series current data at $6^{\circ} \mathrm{N}, 28^{\circ} \mathrm{W}$, collected during the Seasonal Response of the Equatorial Atlantic (SEQUAL) Experiment, was used by Richardson and Reverdin (1987) to describe the temporal variation of NECC. Their data is shown in Figure 2. The NECC was similar in both 1983 and 1984 except that the latter showed greater velocity. It onset rapidly in May and flowed swiftly eastward until December. The mean flow was low from January to May.

The zonal wind stress on the equator is a major external force for generating the equatorial wave, which has significant impact on the NECC. Its variation is crucial for studying the NECC. Figure 3 shows the zonal wind stress, which was measured at $\mathrm{St}$. Peter and St. Paul Rocks (SPPR), located at $1^{\circ} \mathrm{N}, 29^{\circ} \mathrm{W}$. The length of time series is 2.7 years, from February 1983 to November 1985. Its variation has been described by Colin and Garzoli (1987). A comparison of zonal wind stress with current measurement (Figure 2) shows an abrupt intensification of easterly wind in April 1983, followed by the rapid onset of NECC. The time lag between the easterly wind and NECC was nearly one month. After an initial build up, both wind stress and NECC maintained their strength, with a large fluctuation in amplitude until the trade wind collapsed in December 1983. Both the easterly wind and the NECC regained their strength in May 1984. In spite of the shorter time lag between the easterly wind and NECC, the relation between the easterly wind and NECC was similar to the previous year.

The relation between the easterly wind on the equator and the NECC on the offequator might be due to the equatorial long waves. An analytical equatorial long waves model is applied to explore this relationship. The effect of the equatorial waves on the NECC is examined.

\section{ANALYTICAL MODEL AND RESULTS}

A linear, reduced gravity, equatorial $\beta$-plane model fashioned after Cane and Sarachik (1976, 1977, 1981) and as applied by Weisberg and Tang (1983, 1985, 1987, 1990) and Tang and Weisberg (1984) is applied here to study the effect of the equatorial long waves on the NECC. The model is forced from a state of rest by a temporally and spatially varying zonal wind stress distribution. The equations of motion are

$$
\begin{gathered}
\frac{\partial u}{\partial t}-y v+\frac{\partial h}{\partial x}=-\epsilon u+\tau \\
\frac{\partial v}{\partial t}+y u+\frac{\partial h}{\partial y}=-\in v
\end{gathered}
$$


Zonal Velocity $(\mathrm{cm} / \mathrm{sec})$

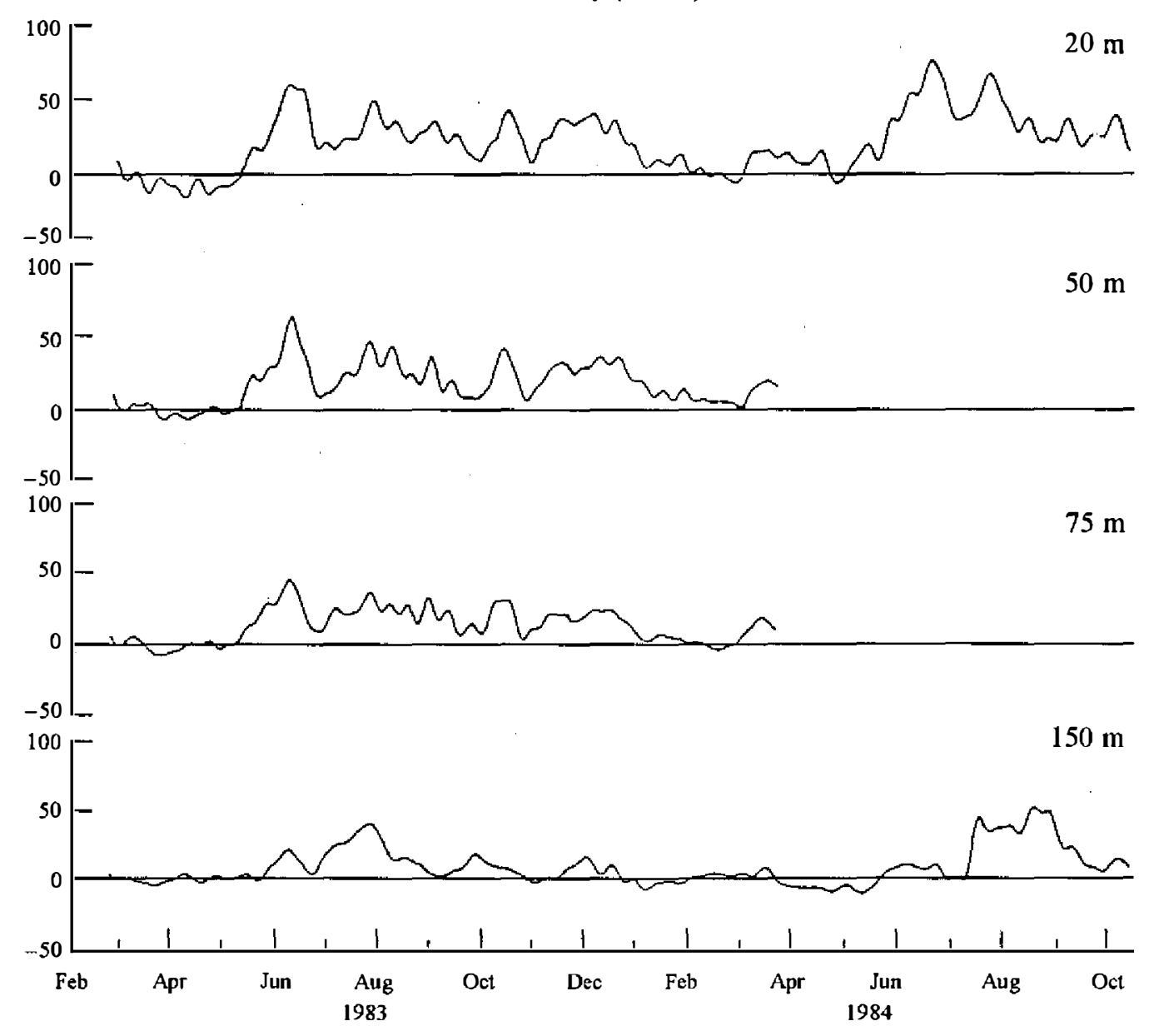

Fig. 2 The zonal current measurement at $20 \mathrm{~m}, 50 \mathrm{~m}, 75 \mathrm{~m}, 150 \mathrm{~m}$, on the $6^{\circ} \mathrm{N}, 28^{\circ} \mathrm{W}$.

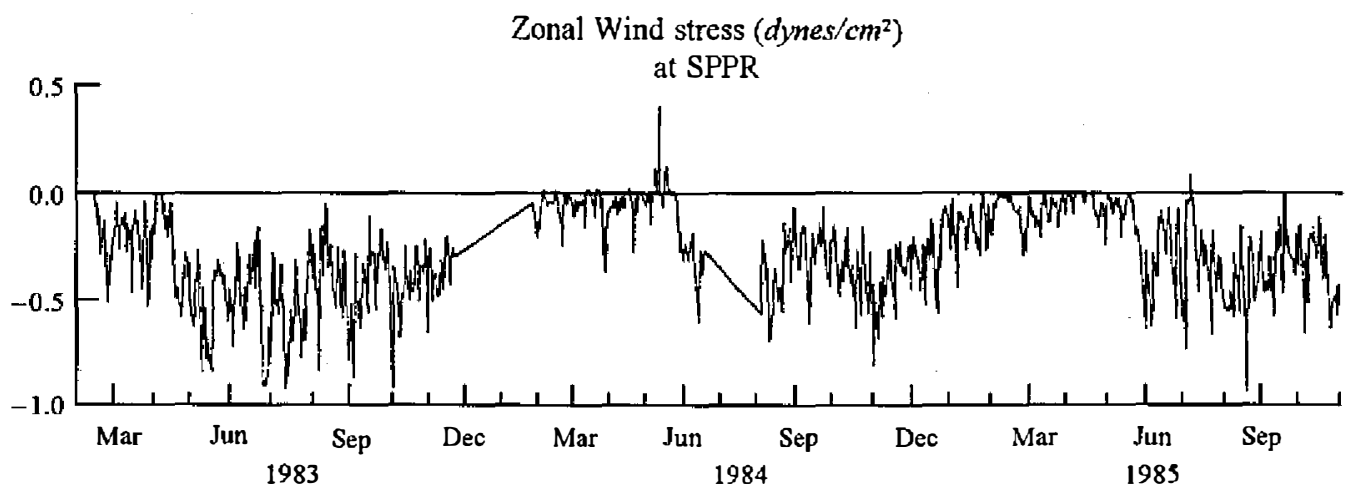

Fig. 3 The wind record at St. Peter and St. Paul Rocks (SPPR) from the February I 983 to December 1985 . 


$$
\frac{\partial h}{\partial t}+\frac{\partial u}{\partial x}+\frac{\partial v}{\partial y}=-\in h
$$

where $u$ and $v$ are the velocity components in both $x$ (east) and $y$ (north) directions, $h$ is the upper layer thickness perturbation, $t$ is time, $\tau$ is the zonal component of wind stress, and $\epsilon$ is a damping parameter. The equations have been nondimensionalized using time and length scales $T=(c \beta)^{-1 / 2}$ and $L=(c / \beta)^{1 / 2}$, where $c=\left(g^{\prime} H\right)^{1 / 2}$ is the reduced-gravity wave speed corresponding to the reduced-gravity $g^{\prime}$ and the undistributed upper layer water depth $H$, and $\beta$ is the gradient in planetary vorticity. The length scale, the time scale and the baroclinic Kelvin wave speed are $267 \mathrm{~km}, 1.92$ days, and $1.6 \mathrm{~m} \mathrm{sec}^{-1}$, respectively. The analytical solution of these equations is discussed by Cane and Sarachik (1976, 1977) for the undamping case and by Weisberg and Tang (1987) for the damping case. The procedure is to Fourier transform the equations of motion, project the forcing function onto the appropriate equatorial wave modes of the homogeneous equations that form a complete set over the interval $-\infty<y<\infty$, integrate these projections in time, and then invert the Fourier transforms using a long wave approximation. The result of the foregoing operations yields the directly forced part of the solution. These forced waves then reflect off of the meridional boundaries to yield the additional long equatorial waves that together comprise the total solution.

The provided damping, Rayleigh friction and Newtonian cooling, is necessary once the integration time of the model becomes long compared to the propagation time for the waves comprising the solution to traverse the basin. Although it provides for damping, it does not distort the form of the undamped equatorial wave solutions that can then be traced analytically through their evolution. In a real sense, dissipative losses in a forced response can occur for a variety of reasons, including eddy exchanges of momentum and heat both laterally and vertically, vertical propagation into the deep ocean, nonlinear interactions with the background currents, and imperfect reflections from meridional boundaries. Weisberg and Tang (1987) studied the model responses for various damping coefficients and suggested that the damping coefficient, 0.01 (the $e$-folding time is 192 days), is more realistic. This value is applied here.

The model domain relative to the equatorial Atlantic Ocean and the meridional distribution of zonal wind stress are shown in Figure 4. Uniform and linear distributed zonal wind stress are also shown in Figure 4. The former one is simple so that its induced ocean response is easily interpreted. The later one has similar distribution with the trade wind on the equatorial Atlantic (Weisberg and Tang, 1987). Dimensionally, the model basin extends from $46^{\circ} \mathrm{W}$ to $8.6^{\circ} \mathrm{E}$ for a total width of $6000 \mathrm{~km}$. The nondimensional force function has the form

$$
\tau(x, y, t)=\gamma e^{-\frac{y^{2}}{2}} X(x) F(t)
$$

where 


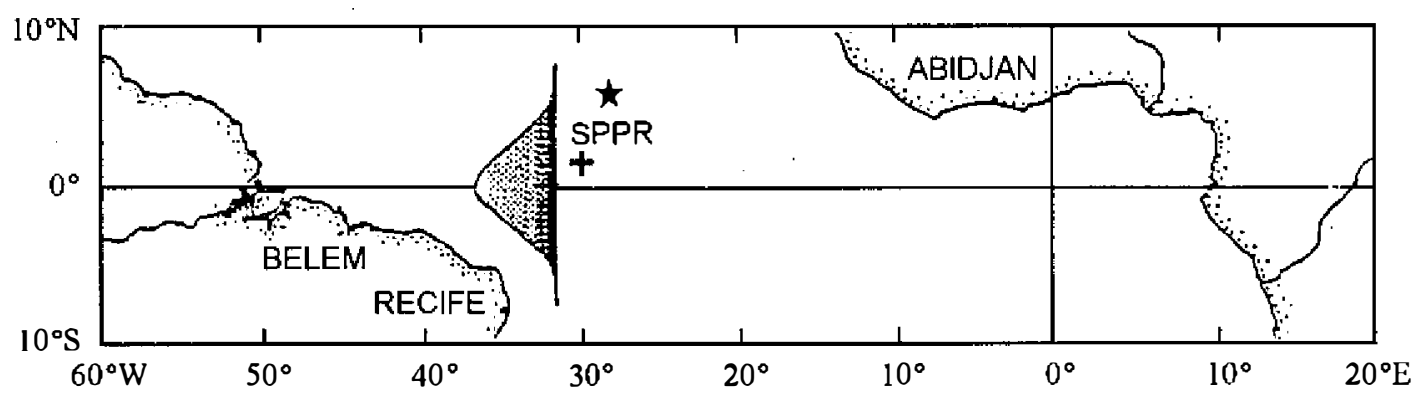

UNIFORM
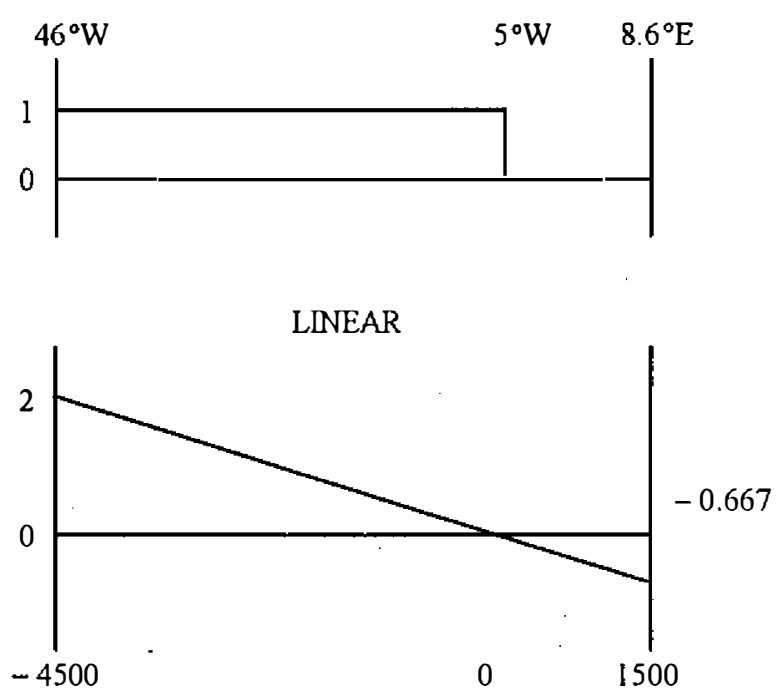

ZONAL POSITION $(\mathrm{km})$

Fig. 4 The model domain and the spatial zonal wind stress distributions. The cross denotes the wind station at SPPR. The asterisk denotes the current measurement at $6^{\circ} \mathrm{N}, 28^{\circ} \mathrm{W}$.

$$
F(t)=H(t) \frac{t}{T_{1}}+\sum_{i=1}^{l} H\left(t-T_{i}\right) S_{i} \frac{t-T_{i}}{T_{i}}
$$

and

$$
X(x)=H(x)-H\left(x+L_{1}\right)
$$

for a uniformly distributed wind stress, or

$$
X(x)=-x\left[H\left(x-L_{2}\right)-H\left(x+L_{1}\right)\right]
$$

for a linearly distributed wind stress, where $H$ represents step function. The parameters of the wind stress are $\gamma$ and $S_{i}$ specifying the magnitude of the variations, $T_{i}$ specifying the 
duration of these variations, and $L_{1}$ and $L_{2}$ specifying the fetches. Dimensionally, the origins of the wind stress distributions are set at $5^{\circ} \mathrm{W}$ with $L_{1}$ and $L_{2}$ equal 4500 and 1500 $\mathrm{km}$, respectively. The amplitude of the easterly wind stress is $0.5 d y \mathrm{~cm}^{-2}$ for the uni-

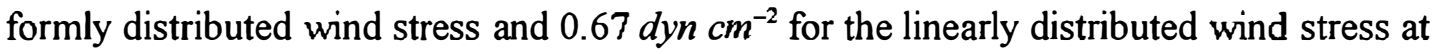
the western boundary.

In order to study the variation of NECC induced by the equatorial long waves in detail, the simplest force function will be applied first. A switched-on-off uniformly distributed easterly wind stress (Eqn. 6) is considered in Case A. Case B considers a switched-on-off linearly distributed easterly wind. This linear distribution of zonal wind stress is in agreement with both the climatology and the synoptic observations, including the limited Seasat mission (Halpern, personal communication, 1986). In Case C, the linear wind distribution associated with a time series which represents the daily average easterly wind stress values obtained from SPPR is considered. Except for Case $\mathrm{C}$, the oceanic responses for no zonal boundary, western boundary only and eastem and westem boundaries are considered to examine the effect of forced and reflected equatorial long waves on the NECC.

\section{a. Case A: Uniform Easterly Wind Stress \\ Switched-on at $t=0$ day and switched-off at $t=300$ day}

An unbounded ocean is considered first. Its zonal velocity and upper layer thickness perturbations at $38^{\circ} \mathrm{W}, 28^{\circ} \mathrm{W}$ and $5^{\circ} \mathrm{W}$ along the $5^{\circ} \mathrm{N}$ are shown in Figure 5. As the wind is switched-on, the downwelling forced first meridional mode Rossby wave is generated immediately. It increases the upper layer thickness and accelerates the velocity eastward at $38^{\circ} \mathrm{W}$ and $28^{\circ} \mathrm{W}$. As the forced Rossby wave passes, the steady state is reached, the downwelling and eastward acceleration cease. The duration of downwelling and acceleration are longer further west, because the response is integrated. The upwelling forced Kelvin wave has only a small influence on the off-equatorial ocean since it decays exponentially with latitude. The variation of velocity and upper layer thickness at the $5^{\circ} \mathrm{W}$ is small because it is only affected by the forced Kelvin wave. A reverse process occurs as the easterly wind is switched-off on Day 300 . The Rossby and Kelvin waves now generate the upwelling and downwelling, respectively, to bring the ocean to a state of rest.

Figure 6 shows the zonal velocity and the upper layer thickness perturbations as a function of $x$ and $y$ on Day 80. The ocean response on this day nearly reaches a steady state. In the western basin, a positive meridional gradient of zonal velocity is located between the equator and $550 \mathrm{~km}$ north of the equator. This strong velocity gradient, especially south of $y=300 \mathrm{~km}$, is a mechanism generating the 25 -day equatorial instability wave (Philander, 1978, Cox, 1980, and Weisberg, 1984). The maximum eastward velocity is found at around $5^{\circ} \mathrm{N}, 550 \mathrm{~km}$ north of the equator. The zero crossing of zonal velocity is at around $3^{\circ} \mathrm{N}$, where the upper layer thickness perturbation has largest value. These features, a maximum eastward velocity at $5^{\circ} \mathrm{N}$ and a ridge of upper layer thickness 

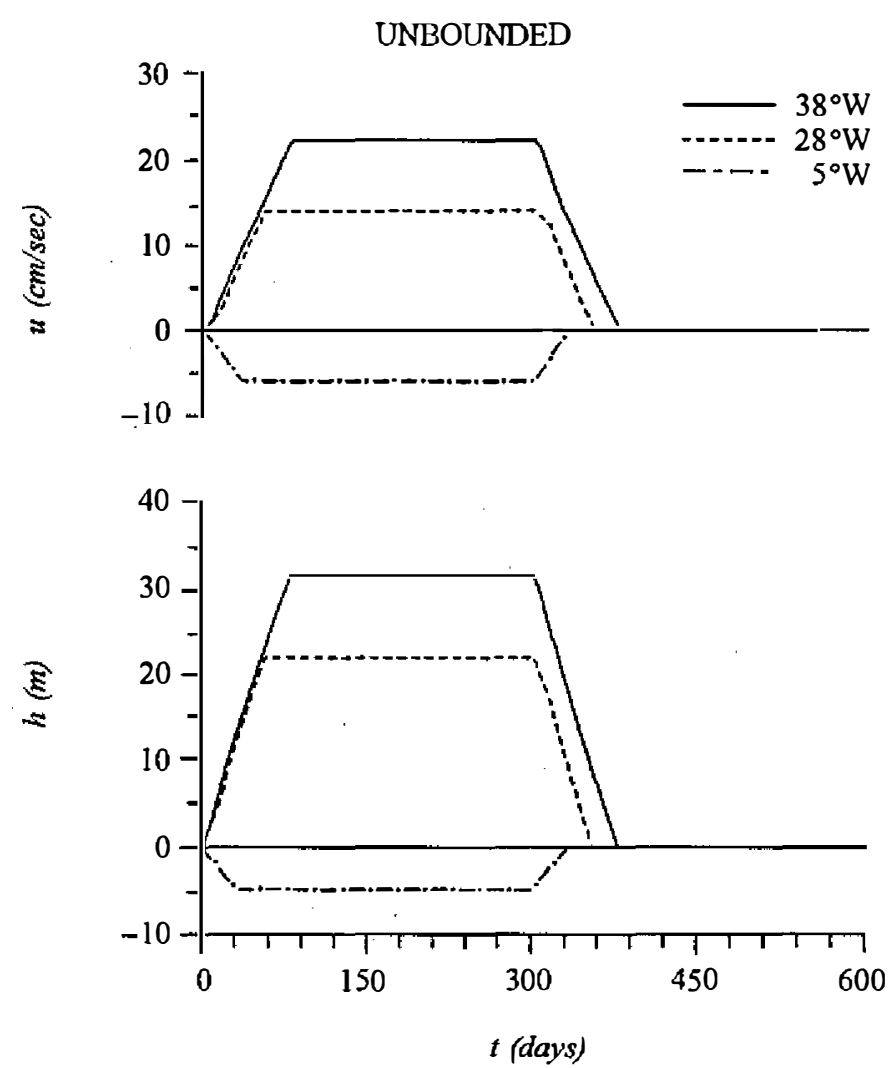

Fig. 5 The zonal velocity and the upper layer ocean thickness perturbations at $38^{\circ} \mathrm{W}, 28^{\circ} \mathrm{W}$ and $5^{\circ} \mathrm{W}$ on the $5^{\circ} \mathrm{N}$ for an unbounded ocean. The uniforn distributed easterly wind stress is switched-on on Day 0 and switched-off on Day 300.

located at $3^{\circ} \mathrm{N}$, is in agreement with the observation (Richardson and Reverdin, 1987) and numerical model result (Chang and Philander, 1989).

In summarizing the above results, the NECC is accelerated immediately by the equatorial forced first meridional mode Rossby wave after the easterly wind is switched-on. Since the Rossby wave is propagating westward, the duration of acceleration of NECC is a function of location, wind fetch, and the Rossby wave speed. It has larger amplitude further west due to the integrated response. The meridional location of the maximum NECC is related with the length scale of the equatorial wave. This length scale is determined by the stratification of the equatorial ocean.

A reflected Kelvin wave will be generated by an additional continental boundary at west. This reflected Kelvin wave is a downwelling wave with eastward velocity. It has only a small influence on the off-equator. Figure 7 shows the zonal velocity and upper layer thickness perturbations at $38^{\circ} \mathrm{W}, 28^{\circ} \mathrm{W}$ and $5^{\circ} \mathrm{W}$ along the $5^{\circ} \mathrm{N}$. Compared to the unbounded ocean response, the reflected Kelvin enlarged the eastward current slightly at $38^{\circ} \mathrm{W}$ and $28^{\circ} \mathrm{W}$ and reduced the westward current slightly at $5^{\circ} \mathrm{W}$. Similar to the zonal 
LONGITUDE
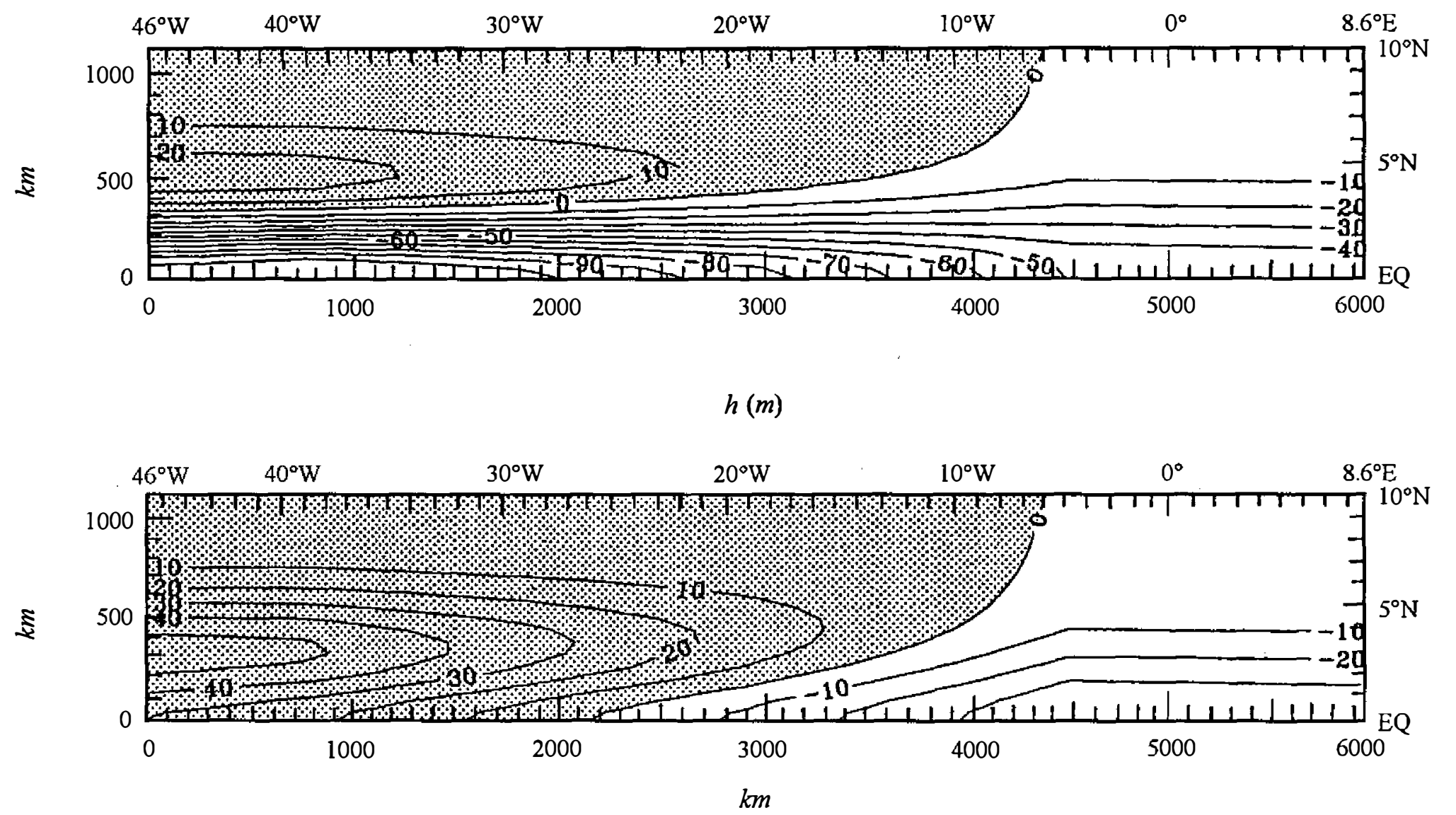

Fig. 6 The zonal velocity and the upper layer thickness perturbations for an unbounded ocean as a function of $x$ and $y$ on Day 80 after the uniform distributed wind stress switched-on. 

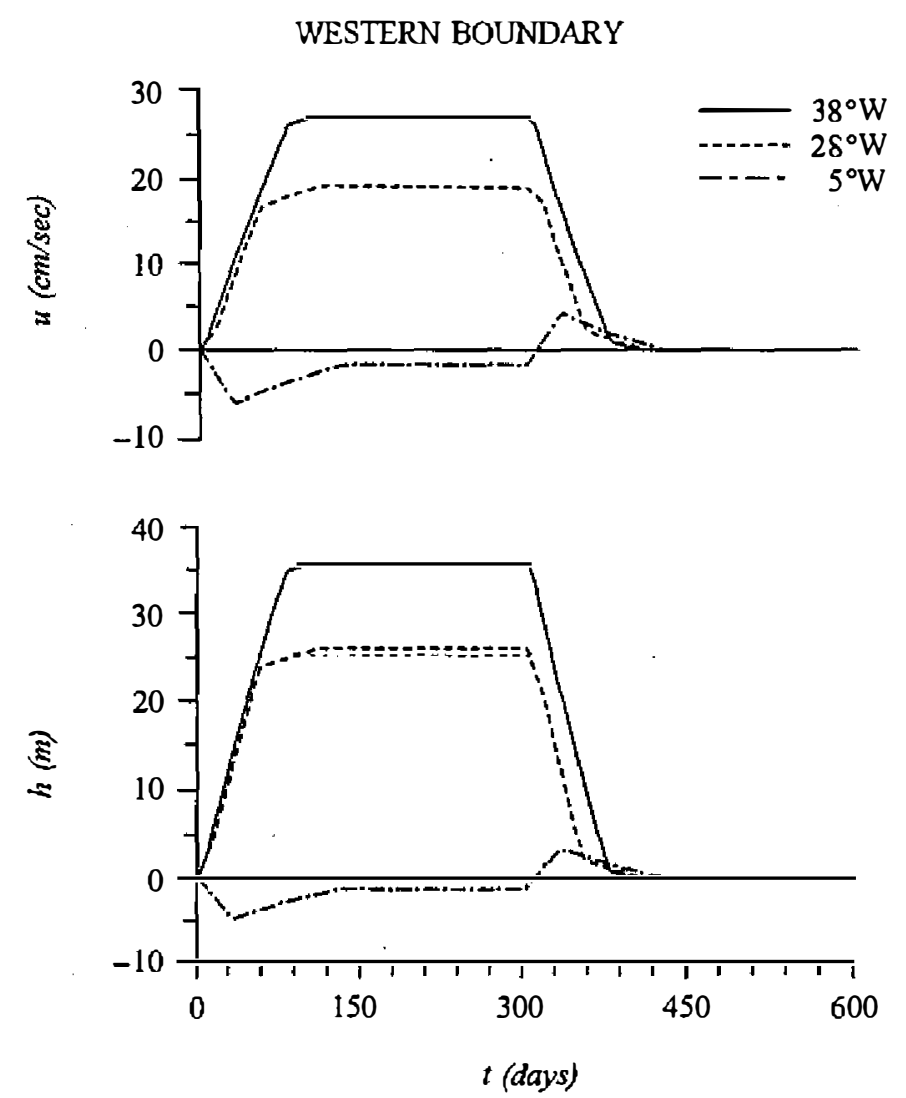

Fig. 7 The zonal velocity and the upper ocean thickness perturbations at $38^{\circ} \mathrm{W}, 28^{\circ} \mathrm{W}$ and $5^{\circ} \mathrm{W}$ on the $5^{\circ} \mathrm{N}$ for a western bounded ocean. The uniform distributed easterly wind stress is switched-on on Day 0 and switched-off on Day 300.

velocity, the upper layer thickness on the off-equator is only slightly modified by the reflected Kelvin wave. As with the previous response for an unbounded ocean, a reverse reaction occurs as the wind is switched-off.

The zonal velocity and upper layer thickess perturbations as a function of $x$ and $y$ on Day 80 are shown in Figure 8. On the off-equator, the reflected Kelvin wave makes the fetch of eastward current shrink and the location of maximum speed shift slightly southward. All of these changes are minor. The major features of the NECC are very similar to the previous case. The change of thermocline on the off-equator is also small. The trough of thermocline is shifted slightly to the south. Unlike the minor influence on the offequator, the reflected Kelvin decelerates the westward velocity on the equator significantly. Therefore, the meridional gradient of zonal velocity in the western basin is reduced.

By imposing an eastern boundary, we now consider the ocean to be bounded by two meridional rigid boundaries. Figure 9 shows the zonal velocity and upper layer thickness 
$u(\mathrm{~cm} / \mathrm{sec})$

\section{LONGITUDE}
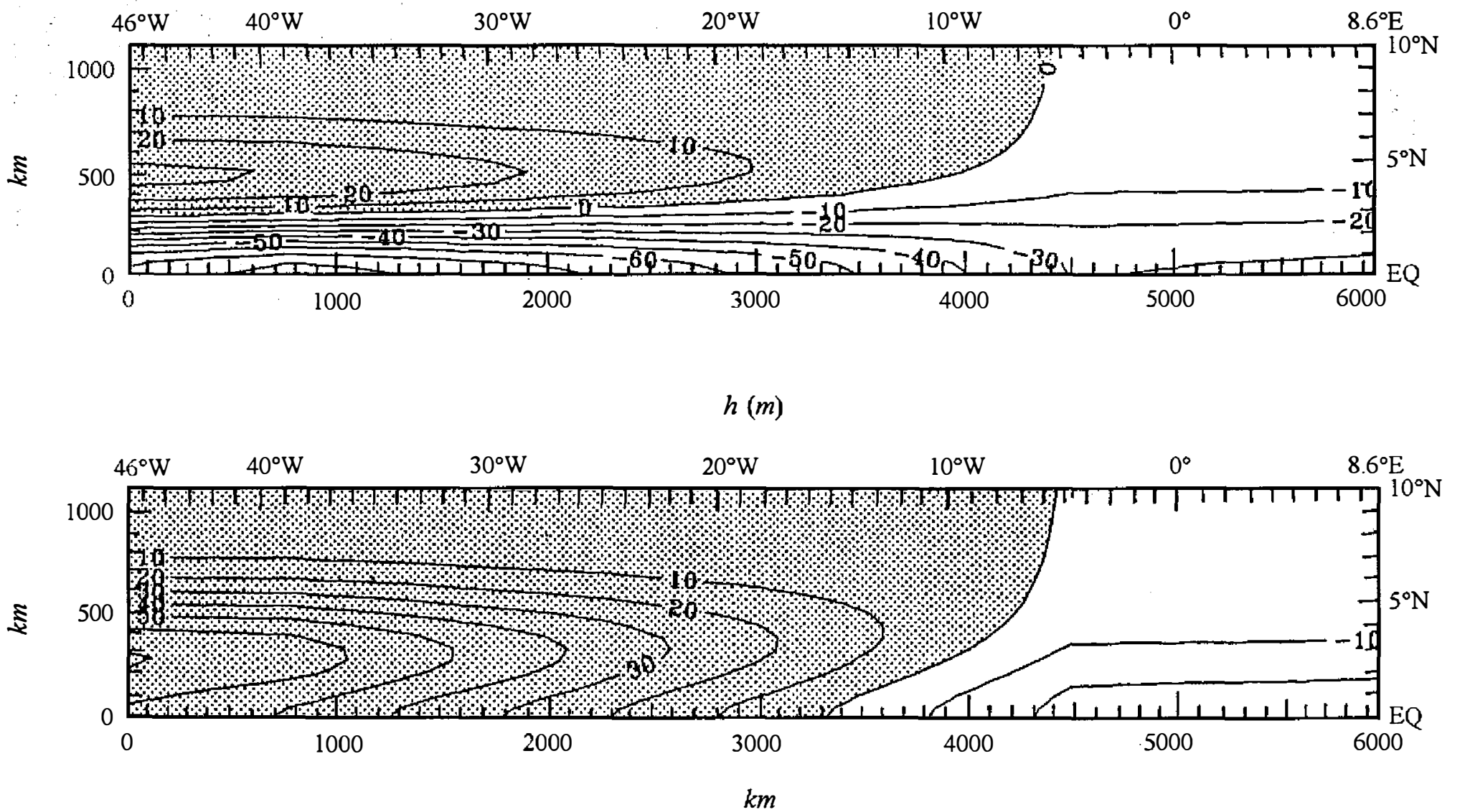

Fig. 8 The zonal velocity and the upper layer thickness perturbations for a western bounded ocean as a function of $x$ and $y$ on Day 80 after the uniform distributed easterly wind stress switched-on. 
WESTERN \& EASTERN BOUNDARIES

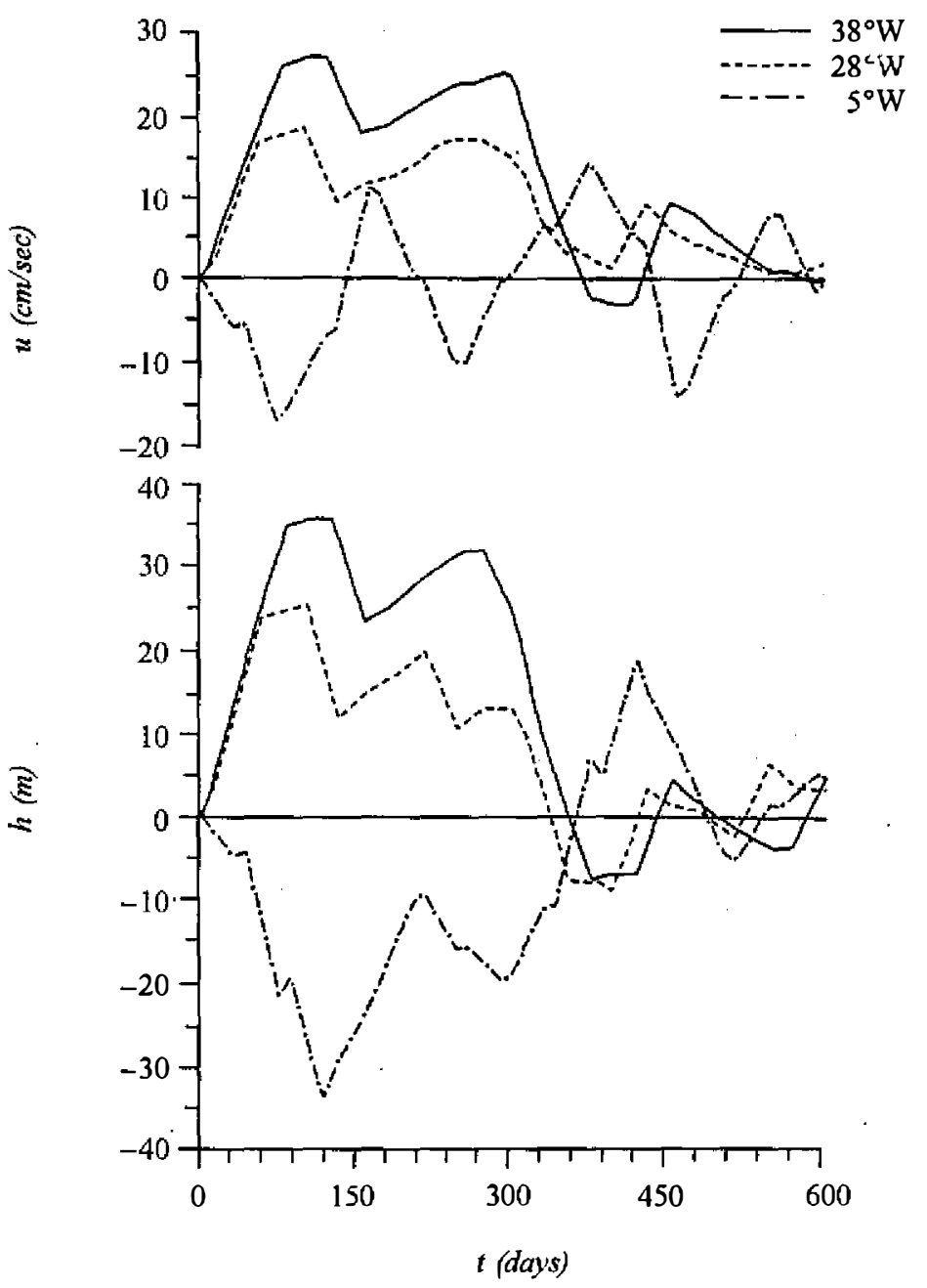

Fig. 9 The zonal velocity and the upper ocean thickness perturbations at $38^{\circ} \mathrm{W}, 28^{\circ} \mathrm{W}$ and $5^{\circ} \mathrm{W}$ on the $5^{\circ} \mathrm{N}$ for a zonal bounded ocean. The uniform distributed easterly wind stress is switched-on on Day 0 and switched-off on Day 300.

perturbations at $38^{\circ} \mathrm{W}, 28^{\circ} \mathrm{W}$ and $5^{\circ} \mathrm{W}$ along the $5^{\circ} \mathrm{N}$. The addition of the eastern boundary generates a series of Rossby waves. Both zonal velocity and upper layer thickness perturbations present a series of oscillations after the initial build up by the forced waves. The oscillations have a larger amplitude at $5^{\circ} \mathrm{W}$ than at $28^{\circ} \mathrm{W}$ or $38^{\circ} \mathrm{W}$ since the Rossby waves, especially the higher meridional mode Rossby waves, are damped as they are propagated to the west. The reflected waves have less influence on the NECC than the forced waves. As the wind is switched-off on Day 300, the NECC is first sharply decelerated by the forced first meridional mode Rossby wave, followed with a series of oscillations. Due to overshooting, a small westward current with short duration is found in the 
western basin after the NECC collapses. The thermocline is brought back to a state of rest by upwelling in the wester basin and downwelling in the eastem basin as the easterly wind is switched-off.

The zonal velocity and upper layer thickness perturbations as a function of $x$ and $y$ on Day 200 are shown in Figure 10. North of $3^{\circ} \mathrm{N}$, the current is generally eastward. The strong eastward current in the western basin is generated by the forced first meridional mode Rossby wave while the weak eastward current in the eastern basin is induced by a series of reflected Rossby waves. This weak eastward current is not a permanent feature. It varies with time as the various meridional mode Rossby waves pass. On the westem basin, a ridge of upper layer thickness is found at around $275 \mathrm{~km}$. Figure 11 shows the zonal velocity and upper layer thickness perturbations as a function of $x$ and $y$ at 400 days, 100 days after the wind switched-off. Generally speaking, the NECC has disappeared. A weak eastward current present in the eastern basin is related with reflected higher meridional mode Rossby waves. Again, this weak eastward current varies with time. The positive value of upper layer thickness perturbation in the eastern basin is a result of overshooting.

Weisberg and Tang $(1987,1990)$ found that a linear distributed zonal wind stress with zero crossing at around $5^{\circ} \mathrm{W}$, is more realistic on the equatorial Atlantic Ocean. Case $\mathrm{B}$ will consider this linear wind distribution and then compare the resulting oceanic response to Case $\mathbf{A}$.

\section{b. Case B: Linear Distributed Easterly Wind Stress \\ Switched-on at $t=0$ day and switched-off at $t=300$ day}

The wind stress distribuiion applied here is described and shown in Figure 4. Figure 12 shows the resulting zonal velocity perturbations at $38^{\circ} \mathrm{W}, 28^{\circ} \mathrm{W}$ and $5^{\circ} \mathrm{W}$ along the $5^{\circ} \mathrm{N}$ for an unbounded, a western bounded and a zonal bounded ocean forced by this type of wind. The basic features here are similar to those in Case A. Since a small fetch of westerly wind stress is generated west of $5^{\circ} \mathrm{W}$, the eastward current at $38^{\circ} \mathrm{W}$ and $28^{\circ} \mathrm{W}$ is first accelerated and then decelerated slightly. This deceleration is related to the westerly wind stress on the eastem basin. Unlike Case A, the acceleration/deceleration in this case is not a constant and is sharper. The zonal velocity and the upper thickness perturbations as a function of $x$ and $y$ on Day 200 for a zonal bounded ocean are shown in Figure 13. The NECC is now more confined to the west but has larger amplitude than in Case A. In the eastem basin, the current is weak. The zonal gradient of both upper layer thickness and zonal velocity is enlarged. The negative value of upper layer thickness perturbation (the upwelling region) is in this case much larger than in Case A. The maximum upwelling is on the equator in the vicinity of the nodal point of wind stress. The maximum downwelling is still located $275 \mathrm{~km}$ north of the equator at the western boundary. Thus, the location of the trough of thermocline remains nearly the same. As the easterly wind collapses, the oceanic response is reversed, similar to that shown in Case A. 


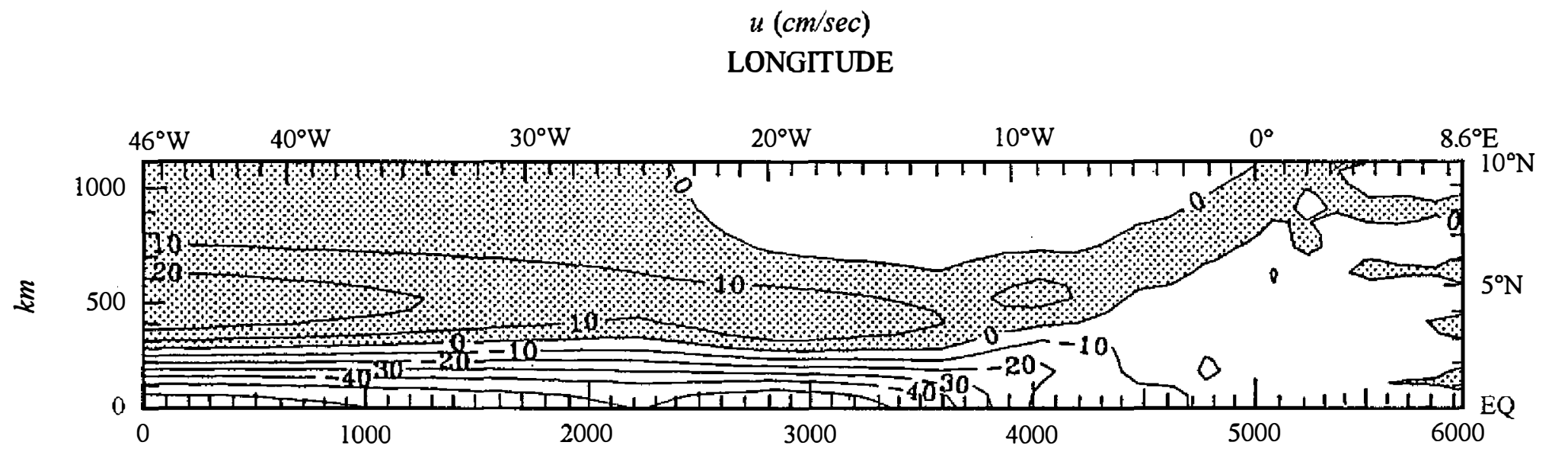

0

1000

2000

3000

4000

5000

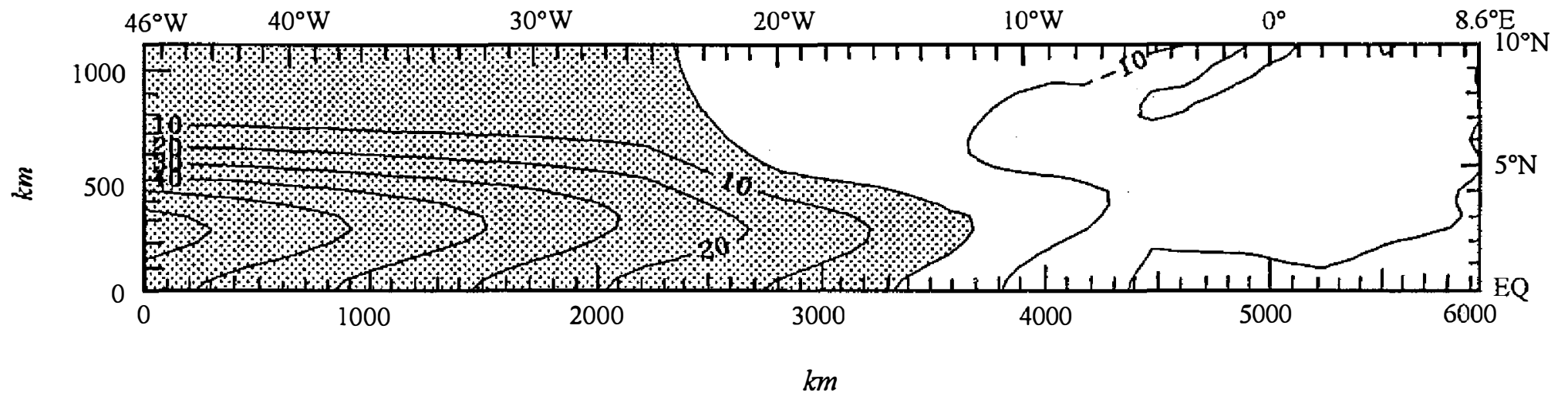

Fig. 10 The zonal velocity and the upper layer thickness perturbations for a zonal bounded ocean as a function of $x$ and $y$ on Day 200 after the uniform distributed easterly wind stress switched-on. 

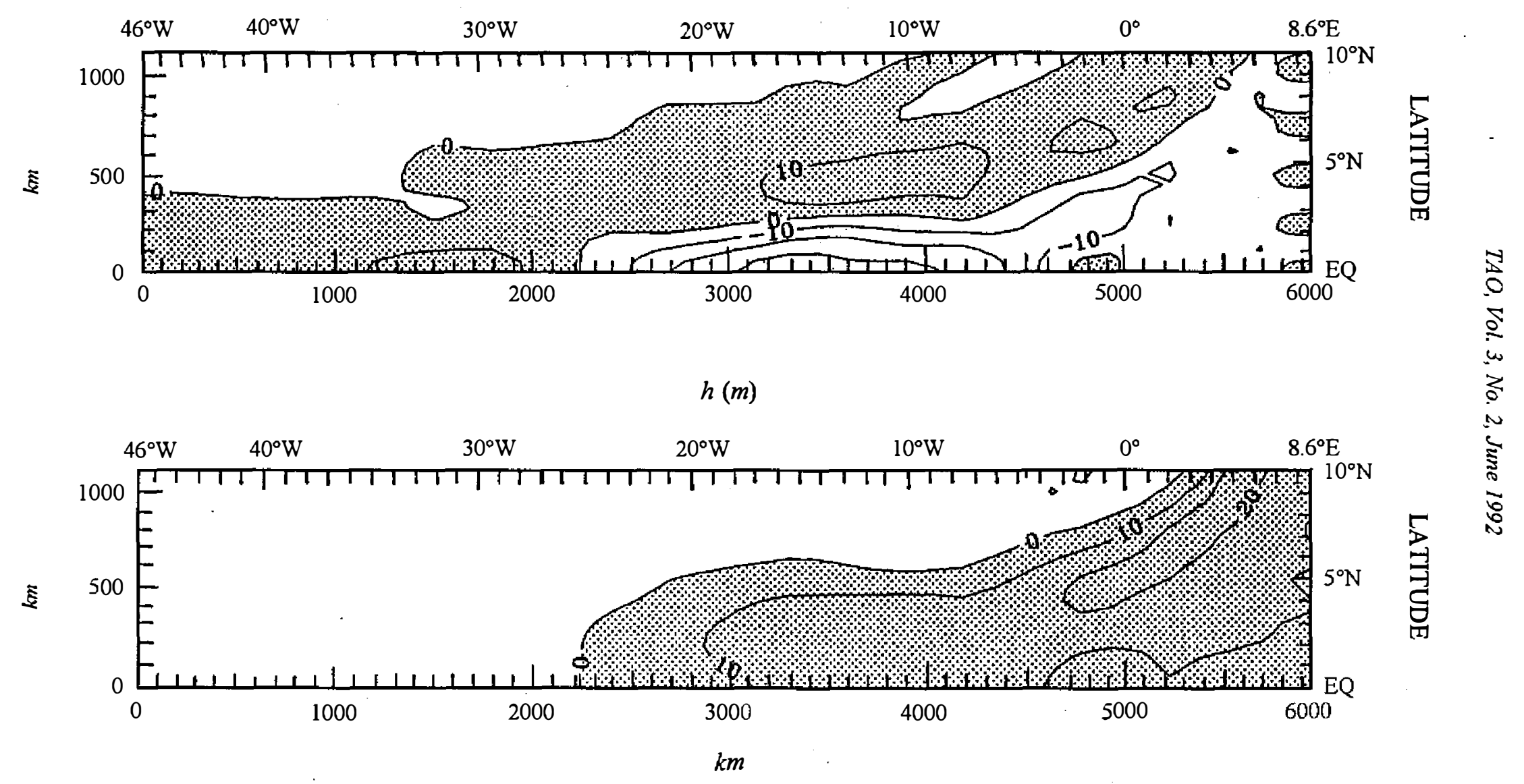

Fig. 11 The zonal velocity and the upper layer thickness perturbations for a zonal bounded ocean as a function of $x$ and $y$ on Day 400,100 days after the uniform distributed easterly wind stress switched-off. 


\section{UNBOUNDED}
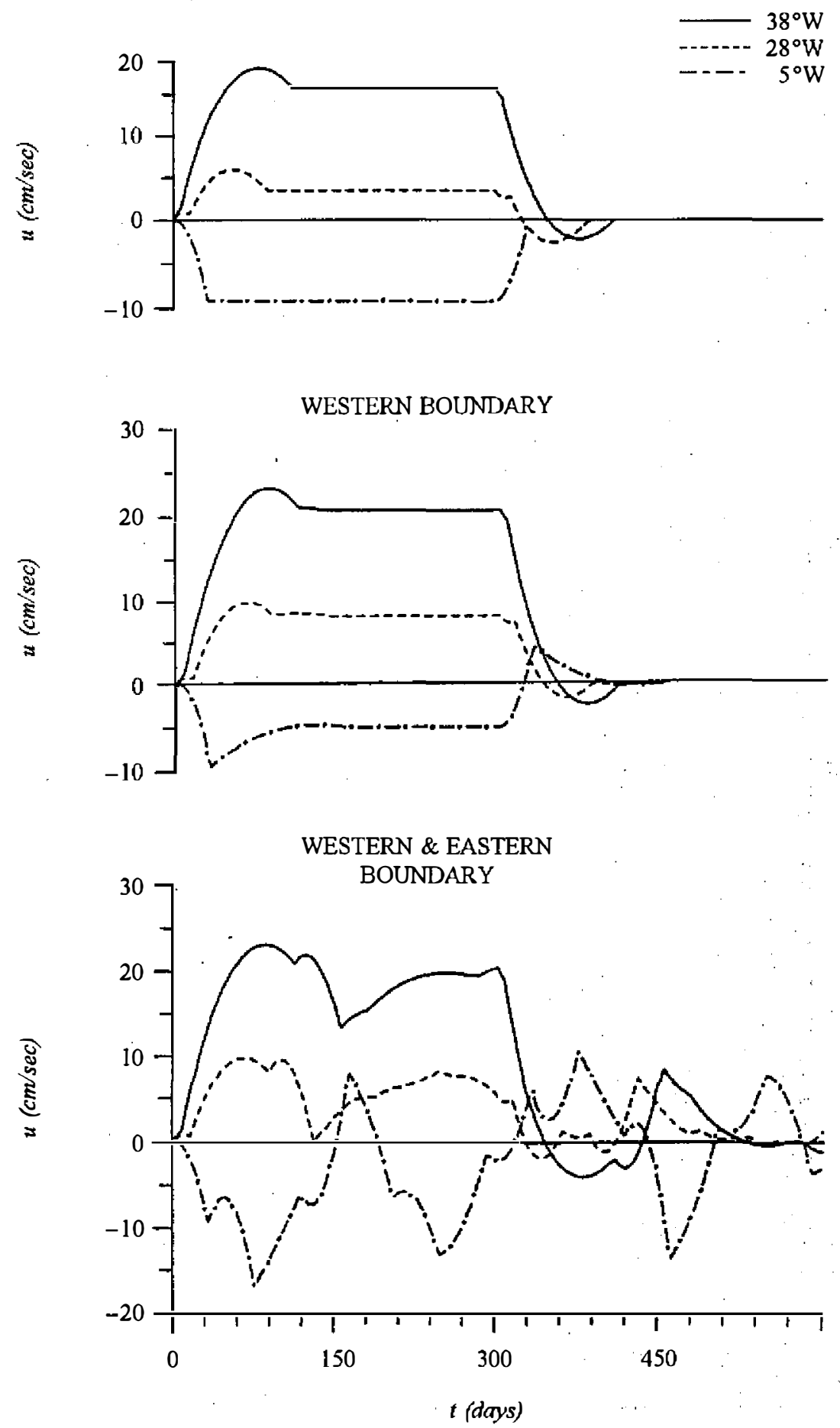

Fig. 12 The zonal velocity perturbations at $38^{\circ} \mathrm{W}, 28^{\circ} \mathrm{W}$ and $5^{\circ} \mathrm{W}$ on the $5^{\circ} \mathrm{N}$ for an unbounded, western bounded only, and zonal bounded oceans. The linear distributed easterly wind stress is switched-on on Day 0 and switched-off on Day 300. 


\section{LONGITUDEE}
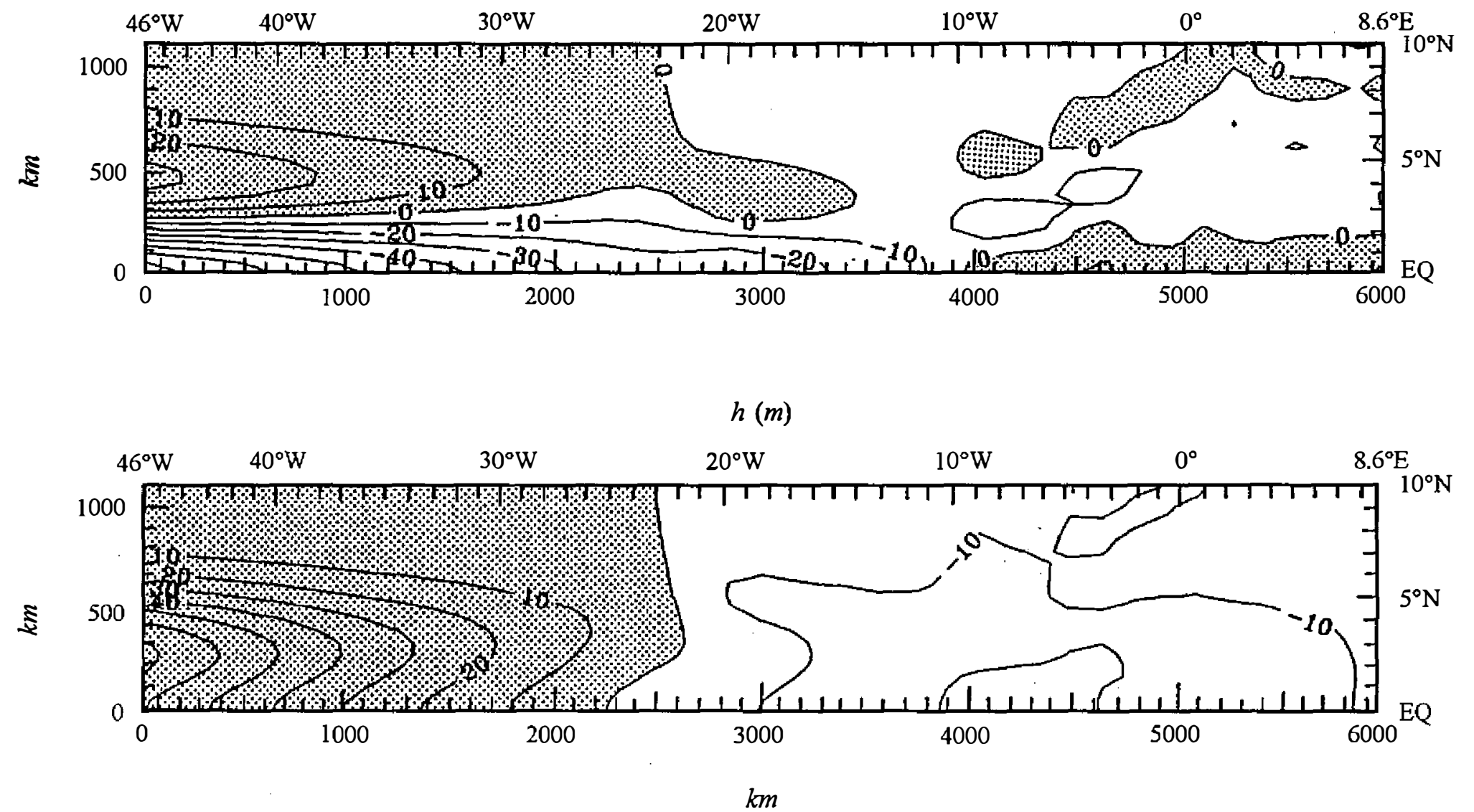

Fig. 13 The zonal velocity distribution and the upper layer thickness perturbations for a zonal bounded ocean as a function of $x$ and $y$ on Day 200 after the linear distributed easterly wind stress switched-on. 
While maintaining the same spatial wind stress distribution, Case $\mathrm{C}$ considers a temporal variation of wind stress very similar to the actual wind measurement recorded at SPPR. Weisberg and Tang (1990) used the exact same wind stress to study the oceanic response on the equator. The model results agreed very well with the observations. The same wind stress and model are applied here, but our attention is now drawn to the oceanic response on the off-equator, especially in the region of the NECC.

\section{c. Case C: Linear Distributed Easterly Wind Stress with Realistic Time Variation}

The applied time series of easterly wind stress is shown in Figure 14. Before the intensification of easterly wind in early April 1983, the trade wind was relaxed. The westerly wind increased for around 10 days and then remained constant for 5 days. The easterly wind built up in 20 days and then kept its strength until December. After the easterly wind collapsed in December, there were no winds for 5 months, and an annual cycle was thus completed. In 1984, the wind intensified in mid-May and collapsed in midNovember. The length of the windless season was nearly the same as before, 5 months. The easterly wind regained its strength in May 1985. The total length of the wind time series in this case is 950 days, from March 27, 1983 to October 31, 1985. The relaxation of easterly wind in 1985 is not included in this time frame. All of the intensification and relaxation of easterly wind stresses occurred rapidly. The corresponding oceanic response for the zonal velocity and upper layer thickness at $38^{\circ} \mathrm{W}, 28^{\circ} \mathrm{W}$ and $5^{\circ} \mathrm{W}$ along the $5^{\circ} \mathrm{N}$ are shown in Figure 15. Since the response at $5^{\circ} \mathrm{N}$ in the western basin is dominated by the forced Rossby wave, its variations are quite in phase with the easterly wind stress variation. Downwelling and rapid acceleration of NECC occurred at $38^{\circ} \mathrm{W}$ and $28^{\circ} \mathrm{W}$ as the easterly wind intensified. The NECC and the upper layer thickness reach their maximum values about one month later. The reflected Rossby waves, originating from the eastern boundary by the reflection of the forced and reflected Kelvin waves, then generated a series of oscillations. The NECC was relaxed as the easterly wind stress collapsed. In the meantime, the upwelling reduced the upper layer thickness. This feature agrees with the finding of Philander and Pacanowski (1987). Due to overshooting, a westward current is displayed for a short period at both $38^{\circ} \mathrm{W}$ and $28^{\circ} \mathrm{W}$ after the wind collapses. A similar annual cycle is repeated in the second and third years. The oceanic response at $5^{\circ} \mathrm{W}$ is quite different from the response further west. Its annual average current is westward but small. The fluctuations of current, which are mainly induced by the reflected Rossby waves, are large. Due to overshooting, the eastward current occurs only for a short period during the strong wind period and again in the no wind season. The perturbation of upper layer thickness at $38^{\circ} \mathrm{W}$ and $28^{\circ} \mathrm{W}$ are nearly in-phase with one another, but both are outof-phase with the perturbation at $5^{\circ} \mathrm{W}$.

Figure 16 shows the velocity perturbation as a function of time and longitude at $5^{\circ} \mathrm{N}$. The NECC immediately built up as the easterly wind abruptly intensified. The NECC is confined to the west of $x=3000 \mathrm{~km}$ (near $18.5^{\circ} \mathrm{W}$ ). Although the westward propagating 


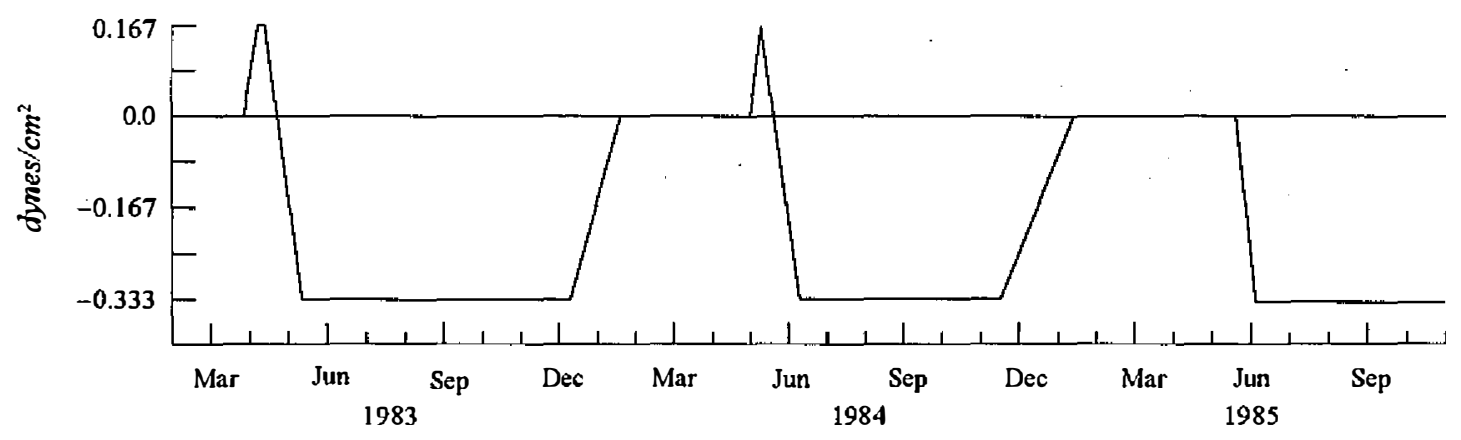

Fig. 14 The representative time series for the easterly wind stress. This time series is used in Case C.

WESTERN \& EASTERN BOUNDARIES
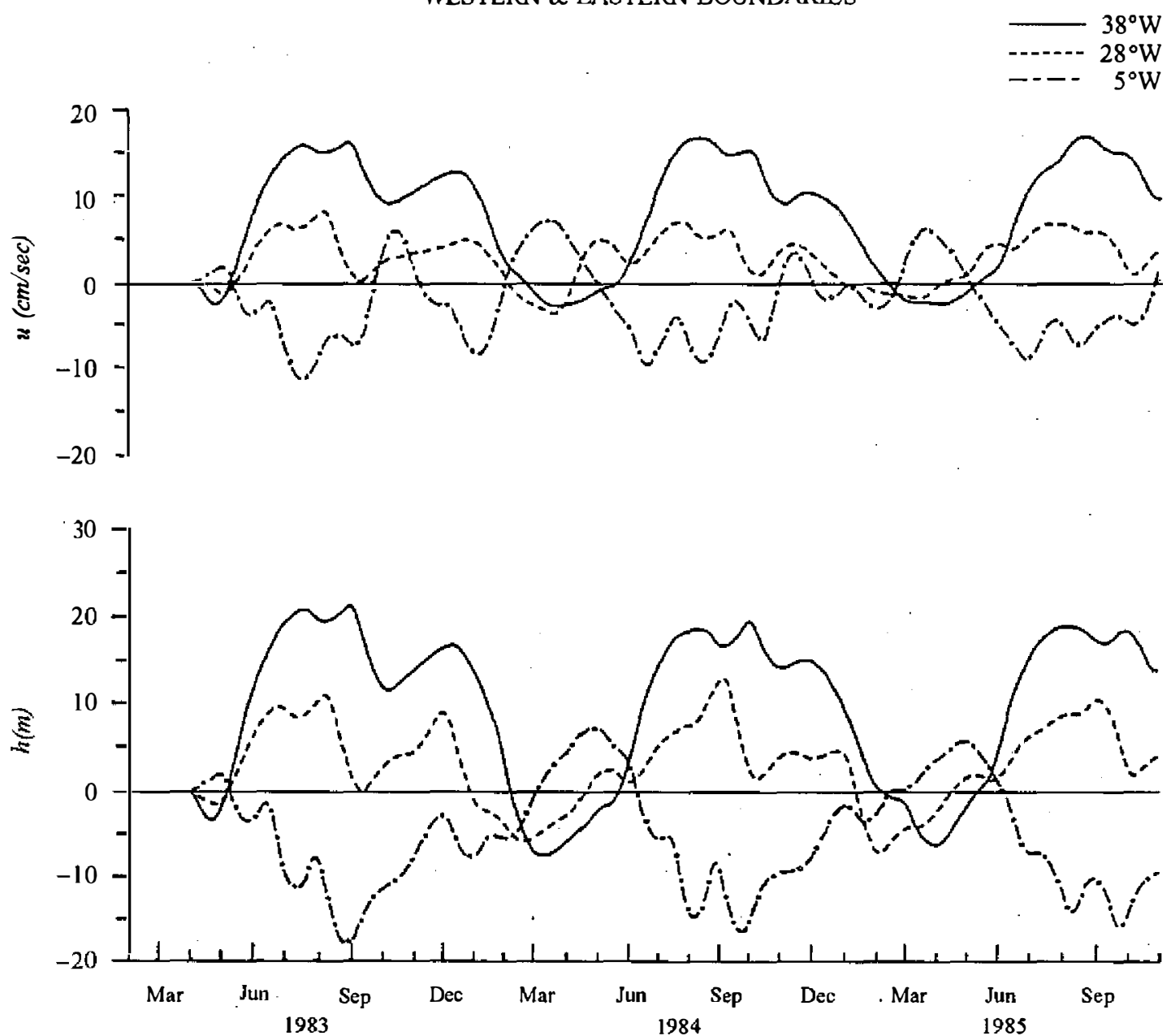

Fig. 15 The zonal velocity and the upper ocean thickness perturbations at $38^{\circ} \mathrm{W}, 28^{\circ} \mathrm{W}$ and $5^{\circ} \mathrm{W}$ on the $5^{\circ} \mathrm{N}$ for a zonal bounded ocean in Case C. 
ZONAL VELOCITY COMPONENT $(\mathrm{cm} / \mathrm{sec})$

LONGITUDE

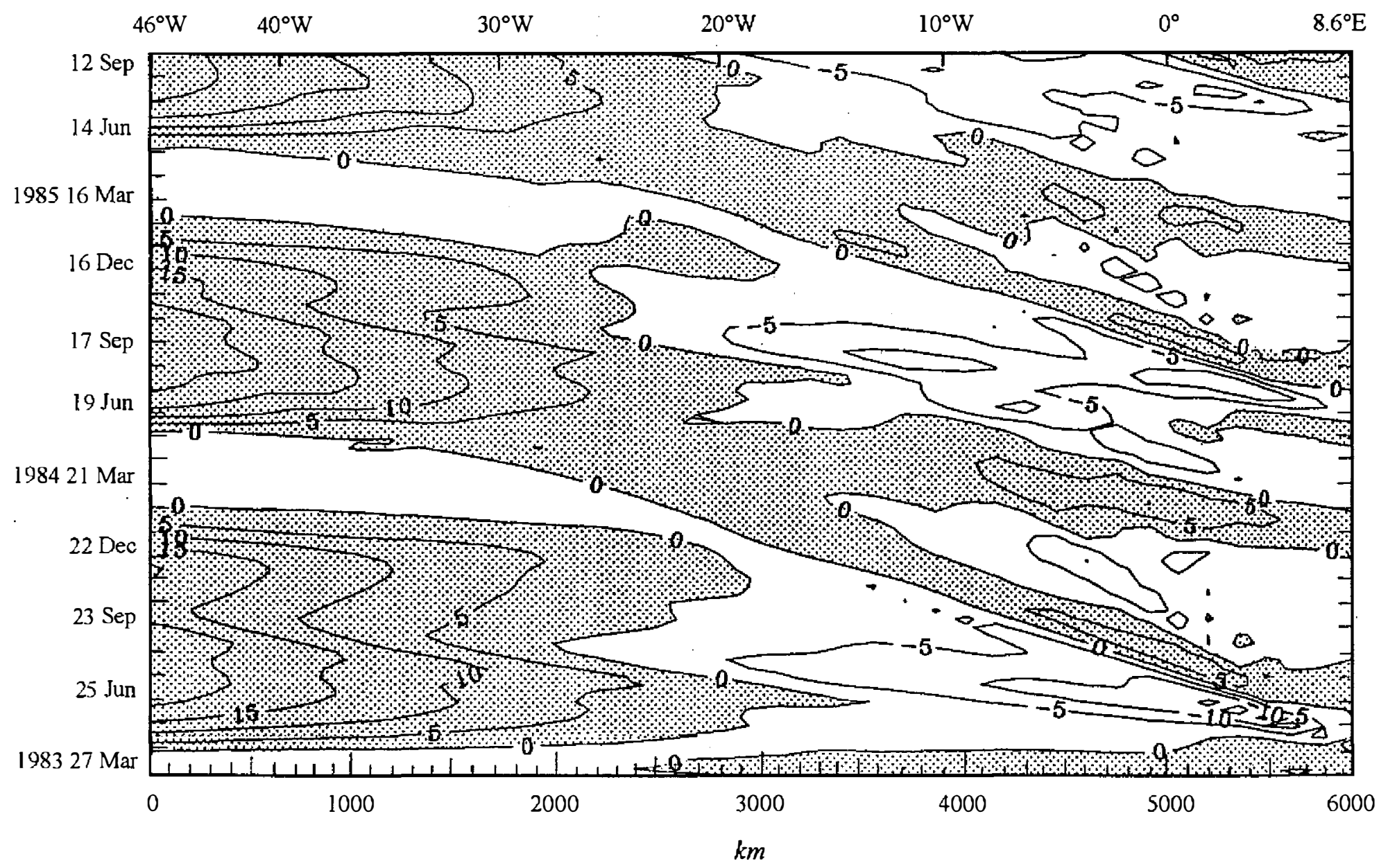

Fig. 16 The contour of zonal velocity perturbation along the $5^{\circ} \mathrm{N}$ as a function of time and longitude. The contour interval is $5 \mathrm{~cm} \mathrm{sec}^{-1}$. 
Rossby waves are mainly responsible for the variation of NECC, this can not be detected from the graph. The difference between the apparent phase speed and the free wave speed in the forced region has been noted by Weisberg and Tang (1987). As the easterly wind collapsed, the NECC disappeared in the western ocean basin, and a temporary reversal of current direction in both basins occurred; overshooting of the zonal gradient as a result of the wind collapse generated oscillations in both basins for a short period.

The oceanic response at $6^{\circ} \mathrm{N}, 28^{\circ} \mathrm{W}$ is also calculated and compared with the observation, shown in Figure 3. The observed zonal current at $50 \mathrm{~m}$ and the model's result are first normalized, and then compared by using a least squared fitting method. This comparison is shown in Figure 17. The shorter line, with more high-frequency fluctuations, is the actual measurement and the other line is the model's output. Agreement between the model's response and observation is good, except for high-frequency variations. This agreement indicates that the equatorial long wave plays a crucial role in the variation of NECC.

\section{DISCUSSION AND CONCLUSION}

A simplist reduced gravity analytical model was applied to study the impact of the equatorial long Rossby wave on the NECC. Three cases were considered. An uniform easterly wind which is switched-on on Day 0 and switched-off on Day 300 was first applied to force the ocean (Case A). The unbounded ocean case allowed us to examine the forced wave response only. The NECC is generated mainly by the forced first meridional mode Rossby wave. The equatorial wave has immediate impact on the NECC as the easterly wind intensifies. Due to the integrated response, the NECC has greater amplitude further west. This finding agrees with previous observation (Richardson, 1984). The

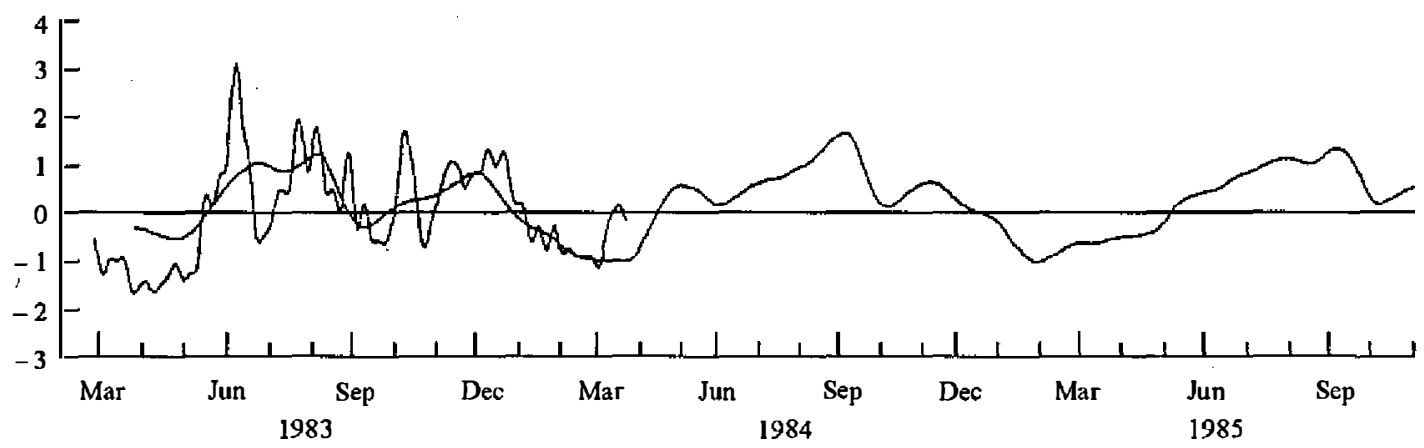

Fig. 17 A comparison between the current velocity observed at $50 \mathrm{~m}$ on $6^{\circ} \mathrm{N}, 28^{\circ} \mathrm{W}$ and model simulated velocity. The time series have been normalized by their standard deviations and superimposed using a linear least squares fit with respect to the ordinate. The units on the ordinate are standard deviations. 
reflected Kelvin wave has only a minor influence on the NECC. For a zonal bounded ocean, the reflected Rossby waves which originate from the eastern boundary can create a series of NECC variations. The model response has a maximum eastward velocity at $5^{\circ} \mathrm{N}$ and a maximum upper layer thickness at $3^{\circ} \mathrm{N}$. All of these features are in agreement with observations as well as with the numerical mode result.

Case B studied the ocean response for a linear distributed zonal wind stress, which is similar to that found by previous observations. The basic features are the same as the features in Case A. The eastward current is more confined to the west but its amplitude and zonal gradient are enlarged. In Case $\mathrm{C}$, the same wind distribution is used. The wind stress applied in Case $\mathrm{C}$ has a temporal variation representative of the low frequency variations of wind measurement at SPPR. The resulting NECC from the model agrees well with the current measurement at $6^{\circ} \mathrm{N}$ and $28^{\circ} \mathrm{W}$. A distinguished annual cycle is displayed in both the model result and the measurement.

Due to the good agreement between the model results and the observations, we conclude that the equatorial long waves have significant impact on the NECC. The forced first meridional mode Rossby wave is mainly responsible for the intensification and relaxation of the NECC.

Acknowledgements This work was supported by the National Science Council of Republic of China, under grants NSC81-0202-M-002-23 and NSC81-0202-M-002-04. The current measurement at $6^{\circ} \mathrm{N}, 28^{\circ} \mathrm{W}$ was provided by Dr. Robert $\mathrm{H}$. Weisberg. Mr. W. T. Lue assisted in preparing the figures.

\section{REFERENCES}

Cane, M. A., and E. S. Sarachik, 1976: Forced baroclinic ocean motions, I The linear equatorial unbounded case. J. Mar. Res., 34, 629-665.

, and

1977: Forced baroclinic ocean motions, II The linear equatorial bounded case. J. Mar. Res., 35, 395-432. , and 1978: The response of a linear baroclinic equatorial ocean to periodic forcing. J. Mar. Res., 39, 651-693.

Chang, P., and S. G. H. Philander, 1989 : Rossby wave packets in baroclinic mean currents. Deep-Sea Res., 36, 17-37.

Colin, C., and S. L. Garzoli, 1987: In situ wind measurements and the ocean response in the equatorial Atlantic during the Programme Français Océan et Climat Dans l'Atlantique Equatorial and Seasonal Response of the Atlantic Ocean Experiment. J. Geophys. Res., 92, 3741-3750.

Cox, M. D., 1980: Generation and propagation of 30-day waves in numerical model of the Pacific. J. Phys. Oceanogr., 10, 1168-1186. 
Delcroix, T., J. Picaut and G. Eldin, 1991: Equatorial Kelvin and Rossby Waves Evidenced in the Pacific Ocean Through Geosat Sea Level and Surface Current Anomalies. J. Geophys. Res., 96, 3249-3262.

Garzoli, S. L., and E. J. Katz, 1983: The forced annual reversal of the Atlantic North Equatorial Countercurrent. J. Phys. Oceanogr., 13, 2082-2090.

Hénin, C., and P. Hisard, 1987: The North Equatorial Countercurrent observed during the programme Français Océan Climate Dans l'Atlantique Equatorial Experiment in the Atlantic Ocean, July 1982 to August 1984. J. Geophys. Res., 92, 3751-3758.

Kessler, W. S., 1990: Observations of long Rossby waves in the northern tropical Pacific. J. Geophys. Res., 95, 5183-5217.

Meyers, G., 1979: On the annual Rossby wave in the tropic north Pacific ocean. $J$. Phys. Oceanogr., 9, 663-674.

Philander, S. G. H., 1978: Instabilities of zonal equatorial currents. J. Geophys. Res., 83, 3679-3682.

and R. C. Pacanowski, 1986: The mass and heat budget in the model of the tropical Atlantic Ocean.J. Geophys. Res., 91, 14212-14220.

Richardson, P. L., 1984: Drifting buoy trajectories in the Atlantic North Equatorial Countercurrent during 1983. Geophys. Res. Lett., 11, $745-748$.

and G. Reverdin, 1987: Seasonal cycle velocity in the Atlantic North Equatorial Countercurrent as measured by the surface drifters, current, and ship drifts. J. Geophys. Res., 92, 3691-3708.

and D. Walsh, 1986: Mapping climatological seasonal variations of surface currents in the tropical Atlantic using ship drifts. J. Geophys. Res., 91, 10537-10550.

Steger, J. M., and J. A. Carton, 1991: Long Waves and Eddies in the Tropical Atlantic Ocean: 1984-1990. J. Geophys Res., 96, 15161-15171.

Tang, T. Y., and R. H. Weisberg, 1984: On the equatorial Pacific response to the 1982/ 1983 El Niño-Southern Oscillation event. J. Mar. Res., 42, 809-829.

Weisberg, R. H., 1984: Instability waves observed on the equator in the Atlantic during 1983. Geophys. Res. Lett, 11, 753-756.

and T. Y. Tang, 1983: Equatorial ocean response to growing and moving wind systems with application to the Atlantic. J. Mar. Res., 41, 461-484.

and , 1985: On the response of the equatorial thermocline in the Atlantic Ocean to the seasonally varying winds. J. Geophys. Res., 90, 7117-7128. and 1987: Further studies on the response of the equatorial thermocline in the Atlantic Ocean to the seasonally varying trade winds. J. Geophys. Res., 92, 3709-3727.

and 1990: A linear systems analysis of equatorial Atlantic Ocean thermocline variability. J. Phys. Oceanogr., 20, 1813-1825. 


\title{
赤道長波對北赤道反流之影響
}

\author{
唐存勇 楊穎堅 \\ 团立台灣大學海洋研究所 \\ 叁明進 \\ 图立台灣大學大氧系
}

摘 要

本文利用一赤道長波理論模式, 研究赤道長波数北赤道 反流之影響。在此模式中海洋運動乃受一東西向風剪力所引 起。由簢而繁的数種不同風場分饰, 將應用於此模式中。由 各風場所引起的直接受力長波及由邊界反射而珄生的反射長 波將被分別䂺究。當風一開始作用於海面, 直接受力引起的 長波分别孚一向西傅彪的羅士培波及一向東傅彪的開的文波 。模式結果顯示流速最大之北赤道反流位於北緯五度附近、 最厚之斜温首位於北䋨三度, 此結果與實際観测資料相吻合 。因開雨文波之振幅隨緯度增加而成指数锐減, 故模式中北 赤道反流的發生與直接受力引起的羅士培波有關。又因羅士 培波向西傅彪增長, 故北赤道反流在西㷫带海洋有較高的流 速。如考虑束、西邊界的影響, 其所產生的一系列反射波, 僅引起一系列振盜。當風剪力作用停止後, 所有作用反轉, 西向的羅士培波將所引發的北赤道反流消雨, 且因反射波的 振蕰作用，在北赤道反流區會發生短整的西向流。待基本的 分析探討過後, 一组較接近實際熟带大西洋風場的模式風場 將應用於此模式。其所得結果與位於北䋨六度、西經二十八 度實際䚐测所得之流速資料相比較, 結果聮示, 二者相似。 故我們認良, 赤道長波對北赤道反流有廎著的影響力, 尤以 直接受力所引起的羅士培波的影響力最爲重要。 